\title{
Body Narrative of the Image of Satan in Paradise Lost
}

\author{
Shenghua Yang \\ School of Foreign Languages, China West Normal University, Nanchong, China \\ Email: yangshenghua2014@sina.com
}

Received 20 January 2015; accepted 18 March 2015; published 19 March 2015

Copyright (C) 2015 by author and Scientific Research Publishing Inc.

This work is licensed under the Creative Commons Attribution International License (CC BY). http://creativecommons.org/licenses/by/4.0/

c) (i) Open Access

\begin{abstract}
Paradise Lost is most widely admired and intensively studied in English literature. Very few of the critics have noticed the body narrative of Satan, the complex and subtle image in Paradise Lost. The gradual degradation of Satan's body is closely linked with his disobedience of hierarchical nature of the universe and his downward moral path. Satan, with heroic qualities, is destined to be punished both in body and in spirit.
\end{abstract}

\section{Keywords}

Satan, Body Narrative, Hierarchical Nature of Universe

\section{Introduction}

\subsection{Literature Review of Satan's Image}

Paradise Lost, Milton's masterpiece, placed the great seventeenth-century English poet Milton beside Shakespeare, Dante, Homer and Virgil in the pantheon of world literature. Satan, one of the main characters in Paradise Lost, failed in the rebellion against the tyranny of Heaven and was cast into the darkness of Hell and led to man's fall from grace. There are many compelling qualities to his character that make him intriguing to literary critics and readers.

Pro-Satanists as Percy Besshe Shelley, William Blake and William Hazlitt champion Satan and view him as a magnificent hero. They emphasize Satan’s pride, courage and rebellious spirit. In Shelley’s eyes, Satan is a devil, but "very different from the popular personification of evil” (Miller, 1997: p. 148). He clarifies his stand in "On the Devil, and Devils” that "Milton's Devil, as a moral being, is as far superior to his God, as one who perseveres in a purpose which he has conceived to be excellent, in spite of adversity and torture, is to one who in the cold security of undoubted triumph inflicts the most horrible revenge upon his enemy-not from any mistaken notion of bringing him to repent of a perseverance in enmity, but with the open and alleged design of exasperat- 
ing him to deserve new torments” (Miller, 1997: p. 148). However, anti-Satanists such as Charles Williams and C. S. Lewis depreciate Satan and regard him as a depiction of pure devil. They emphasize Satan's selfishness, folly or absurdity. As viewed from C. S. Lewis, “throughout the poem, all his (Satan's) torments come, in a sense, at his own bidding” (Lewis, 1942: p. 99). And he believes that Satan's revolt against God "is entangled in contradictions from the very outset” because "he only thought himself impaired” (Lewis, 1942: p. 96).

Some literary critics hold the opinion that one source of Satan's fascination for us is that he is extremely complex and subtle character. John Carey indicates that Satan is an ambivalent figure. He points out that "a more reasonable reaction is to recognize that the poem is insolubly ambivalent, in so far as the reading of Satan's character is concerned, and that this ambivalence is a precondition of the poem's success-a major factor in the attention it has roused" (Carey, 2000: p. 161). He argues that the views trying to prove that Milton really means Satan to be essentially evil, or essentially heroic, would destroy much of the poem's power and interest.

However, according to some critics, Satan's rebellion, to some extent, equals British revolution and Satan is almost equal to Milton himself, a true revolutionist. Thus, research on Paradise Lost and the image of Satan is limited by that kind of improper analysis. It is very necessary to explore image of Satan again because Satan occupies the unique position in Paradise Lost, who has been the most successful character and easy to sympathize with. As Satan is much more like us than God or the Son is, he is much easier for us to imagine and empathize with than an omniscient deity. This article will explore deep meaning of the image of Satan from the perspective of body narrative based upon the hierarchical nature of the universe in Pythagorean Cosmology.

\subsection{Pythagorean Cosmology and Hierarchical Nature of Universe}

Cosmology means the composition of the universe, how our world is put together. It comprises our beliefs about the fundamental constituents of the environment. "So actually, cosmology is an analysis of ultimate reality. Many different things have at one time or another been urged as the elemental components of reality. A few of the better known include atoms (both in classical times and in our own), the sense data of humans, the mental impressions of humans, bundles of energy, electronic fields, ideas in the Platonic sense, numbers as defined by the Pythagoreans, and basic qualities (such as hot, cold, moist, and dry). Cosmology consists in designating the intrinsic ingredients of reality and defining the interrelations between them” (Heninger, 1974: p. 6).

According to cosmology, the cosmos is dominated by a well-ordered, harmonious circular movement. It is also a kind of perfect and limited space, which is arranged in an ordered hierarchy, ranging from the lowest to the highest. The earth rests at the center of it. Cosmology emphasizes the relationship between cosmos and man, the interactions of all levels. The chain of being is an attempt to deal with metaphysical problem. The physical realm is comprised of (in ascending order) stones, plants, and animals, and the conceptual realm is comprised of (in descending order) God and the angels. And man is the nexus between them, holding the physical and the conceptual together in a single entity and providing a means of intercourse between them. Man is literally the crucial link between them.

\section{Discussion}

Satan's character and psychology are all very human. His envy, pride, and despair are understandable given his situation. Satan's character, or our perception of his character, changes significantly from Book I to his final appearance in Book X. The change of Satan's character is closely related to the change of his body. As is known to all, to obey God will allow human beings to create an inner Paradise. In contrast, to disobey God and to destroy hierarchical nature of universe will definitely make Satan's body change from higher level to the lower. Thus, Satan, far from being freed from Hell, is doomed to be punished and live in a state of Hell. Even though Satan is in Paradise, he feels as if he is still in Hell. That is to say, Heaven and Hell become more than just a place; they become a state of mind.

\subsection{Hierarchical Nature of Universe in Paradise Lost}

The universe is, generally according to Milton's viewpoint of religion, divided into four major regions: glorious Heaven, Dreadful Hell, confusing Chaos, and a young and vulnerable Earth in between. "With the established settings of good and evil, light and dark, much of the action occurs in between on Earth” (Shawcross, 1993: p. 28). 
Paradise Lost is about hierarchy as much as it is about obedience. "The layout of the universe-with Heaven above, Hell below, and Earth in the middle-presents the universe as a hierarchy based on proximity to God and his grace” (Shawcross, 1993: p. 29). The spatial hierarchy leads to a social hierarchy of angels, humans, animals, and devils. The Son is closest to God, with the archangels and cherubs behind him. Adam and Eve and Earth's animals come next, with Satan and the other fallen angels following last. To obey God is to respect this hierarchy.

Satan refuses to honor the Son as his superior and questions God's hierarchy. When the angels in Satan's camp rebel, they hope to beat God and thereby dissolve an unfair hierarchy in Heaven they believe to be. The rebels are punished by being banished far away from Heaven, when the Son and the royal angels defeat the rebel angels. Satan argues later, they can make their own hierarchy in Hell at least, but they are still subject to God's overall hierarchy, in which they are ranked the lowest. Satan continues to disobey God and his hierarchy. So it makes sense that he seeks to corrupt mankind.

Likewise, humankind's disobedience is a corruption of God's hierarchy. Before the fall, Adam and Eve treat the visiting angels with proper respect and acknowledgement of their closeness to God, and Eve embraces the subservient role allotted to her in her marriage. When Eve persuades Adam to let her work alone, she challenges his superior position and Adam yields to Eve, his inferior. Again, when Adam eats the fruit, he knowingly defies God by obeying Eve and his inner instinct instead of God and his reason. Adam's visions in Book XI and XII show more examples of this disobedience to God and the universe's hierarchy, but also demonstrate that with the Son's sacrifice, this hierarchy will be restored once again.

\subsection{Body Opposites Abound in Holy Trinity and Evil Trinity}

Paradise Lost includes many characters who can be easily compared and contrasted with each other. God and Satan stand as complete opposites. Holy Trinity is consisted of God, Son and Spirit, whereas Satan, Sin and Death form an evil version of the Holy Trinity. The two opposites have great differences from the perspective of body and these differences give good answers to the question: Why bodies of Evil Trinity are ugly, evil, ill-favored and unsightly?

As is known to all, body narrative in Holy Trinity is very significant and vivid. All the descriptions of Holy Trinity are full of praises and celebrations. God, in Paradise Lost is less a developed character than a personification of abstract ideas. He is unknowable to humankind and to some extent lacks emotion and depth. Although God does not have visible body, he is omniscient, omnipresent and omnipotent, who knows everything before it happens. He has no weaknesses, embodies pure reason, and is always just. God plans to save humankind through offering Son's body and controlling Satan's body. For Milton, the Son is the manifestation of God in body and in action. While God, the father, stays in the realm of Heaven, the Son performs the difficult tasks of banishing Satan and his rebel angels, creating the universe and humankind, and punishing Satan, Adam and Eve with justice and mercy. The Son physically connects God, the Father, with his creation. The Son also personifies love and compassion. His decision to volunteer to die for humankind shows his dedication and selflessness. Through body's suffering, the Son's sacrifice on the cross, the Son is able to accomplish his task to save humankind and to give Adam and Eve restored hope.

Satan disobeys God, challenges God's authority and rebels against God. In this sense, Satan breaks the hierarchical nature of universe and his fall is destined. Undoubtedly, his body is doomed to be punished by God. In Book I he is strong, imposing figure with great abilities as a leader and public statesmen, whereas by the poem's end he slinks back to Hell in serpent form. Satan's gradual degradation is dramatized by the sequence of different shapes of body he assumes. Sin is Satan's daughter, who sprang full-formed from Satan's head when he was still in Heaven. Sin has the shape of a woman above the waist that of a serpent below and her middle is ringed about with Hell Hounds, who periodically burrow into her womb and gnaw her entrails. Death is Satan's son by his daughter, Sin. Death in turn rapes his mother, begetting the mass of beasts that torment her lower half. In Book II, Satan's encounter with Sin and Death is an allegory, in which the three characters and their relationships represent abstract ideas stemmed from concrete bodies. Sin is the first child of Satan, brought to life by Satan's disobedience. Since Satan is the first of God's creation to disobey, he personifies disobedience, and the fact that Sin is his daughter suggests that all sins arise from disobedience and ingratitude towards God. To those who behold her birth, she is first frightening but then seems strangely attractive, suggesting the seductive allure of sin to the ordinary individual. Sin dwells alone and in utter torment, representing the ultimate fate of the sin- 
ners. That Death is Sin's offspring indicates Milton's belief that death is not simply a biological fact of life but rather a punishment for sin and disobedience, a punishment that nobody escapes.

\subsection{Change of Satan's Body}

Satan’s body changes significantly from Book I to his final appearance in Book X. The change of Satan's body demonstrates the fact that disobedience of the hierarchical nature of universe in moral sense results in the gradual degradation in body. "Satan begins the poem as a just-fallen angel of enormous stature, looks like a comet or meteor as he leaves Hell, then disguises himself as a more humble cherub, then as a cormorant, a toad and finally a snake” (Fish, 1967: p. 12). His ability to reason and argue also deteriorates.

Through the first two or three books of Paradise Lost, Satan seems as if he is the hero of the poem. This is partly because the focus of the poem is all on him, but it is also because the first books establish his strugglehe finds himself defeated and banished from Heaven, and sets about establishing a new course for himself and those he leads. "One important way in which the narrator develops our picture of Satan-and gives us the impression that he is a hero-is through epic similes, lengthy and developed comparisons that tell us how big and powerful Satan is” (Fish, 1967: p. 13). For example, when Satan is lying on the burning lake, Milton compares him to the Titans who waged war upon Love in Greek mythology. Then at a greater length, he compares him to a Leviathan, or whale, that is so huge that sailors mistake it for an island and fix their anchor to it. In the beginning of the poem, Satan, as a fallen angel, has a big body and a heroic image. Satan displays all of the virtues of a great warrior such as Achilles and Odysseus. He is courageous, undaunted, refusing to yield in the face of impossible odds, and able to stir his followers to follow him in brave and violent exploits.

In Book III, Satan lands on earth and is drawn by the golden sun, hanging above the green and lush land. He flies towards it and sees an angel standing on a hill. To deceive him, Satan changes to a low-ranking angel. Recognizing the other angel as the Archangel Uriel, Satan approaches and addresses. Satan's transformation and his speech are so flawless that even Uriel cannot see through the subterfuge. The encounter between Satan and Uriel demonstrates Satan's capacity for deception and fraud, as he subverts Uriel's role as a guardian by disguising himself as a cherub. Through Satan's deception of Uriel, Milton shows the significance of the sin of fraud, or hypocrisy. Fraud is an especially damaging sin because it is visible to others, hurting them in ways they are not even aware of. Milton has the opinion that leading innocent people to evil is much worse than leading you to evil.

Satan is later described as leaping over Eden's fence like a wolf into a sheep's pen. While he does not exactly take the form of a wolf, he continues to be compared to and associated with wild, predatory animal. He takes the shape of a bird on the top of the Tree of Life, and then morphs into a toad to whisper temptation into Eve's ear. Satan's shapes become progressively less impressive and stately. Once as an imposing figure, he shrinks himself to become a lesser angel, then a mere bird, and finally a much less appealing animal: a toad. Finally, Satan, in the form of serpent, flatters Eve by saying that eating the apple will make Adam seek her out in order to worship her beauty. While in Hell, Satan tells himself that his mind could make its own Heaven out of Hell. Hell is not simply a place, but rather a state of mind brought on by a lack of connection with God. He brings Hell with him wherever he goes.

\section{Conclusion}

Satan, generally in some readers' eyes, is considered to be the hero, or protagonist, of the story, because he struggles to overcome his own doubts and weaknesses and accomplishes his goal corrupting humankind. This goal, however, is evil, and Adam and Eve are the moral heroes at the end of the story, as they help to begin humankind's slow process of redemption and salvation. Satan is far from being the story's object of admiration as most heroes are. Nor does it make sense for readers to celebrate or emulate him, as they might with a true hero.

Influenced by the misunderstanding of John Dryden and William Blake on the image of Satan in John Milton's Paradise Lost, most scholars consider that the work is to publicize the devil's spirit of rebellion, and Milton, taking the side of Satan, expressed the spirit of revolution in $17^{\text {th }}$ century in his long poem. In fact, according to Milton, Good and Evil are the twins, jumping from one apple to this world. Heaven and Hell are also in the same state. Although they are two places and differ a lot from their appearances, they originate from the same mind. If one's mind is in a bad state, he will probably disobey God's order and the hierarchical nature of the world. Naturally evil occupies his mind. The result is that he will be punished by God and be cast into Hell. 
Milton's Satan is a good case. On the contrary, if one's mind is in a good state and obeys God's order, he will definitely hold Virtue in his mind and be rewarded to live in a state of Heaven, no matter what kind of sin he has committed. Adam in Paradise Lost is also a good example.

Satan's image of rebellion and fall is well-analyzed in this thesis through the deep exploration of the relationship between disobedience of hierarchical nature of universe and Satan's body degradation from the new perspective of body narrative. Satan's body change from the higher to the lower is an obvious reflection of his character, of his state of mind from the higher to the lower. In this sense, Satan is certainly the most successful character in Milton's Paradise Lost, for his body narrative is also closely related to Milton's own body change and the revolutionary situation in Milton's time.

Admittedly, it is necessary to do further study about body narrative in Milton's Paradise Lost. A deep exploration is needed in the relationship between Satan's body narrative and the historical background of Milton's masterpiece, and in the close link between Satan's body narrative and Milton's viewpoint of religion, of Puritanism and of his own revolutionary belief.

\section{References}

Carey, J. (2000). Milton's Satan in Dennis Danielson. Shanghai: Shanghai Foreign Language Education Press.

Fish, S. (1967). Surprised by Sin: The Reader in Paradise Lost. Cambridge: Harvard University Press.

Heninger, S. K. (1974). Touches of Sweet Harmony: Pythagorean Cosmology and Renaissance Poetics. USA: Kingsport Press.

Lewis, C. S. (1942). A Preface to Paradise Lost. London: Oxford University Press.

Miller, T. C. (1997). The Critical Response to John Milton's Paradise Lost. London: Greenwood Press.

Shawcross, J. T. (1993). John Milton: The Self and the World. Lexington, KY: University Press of Kentucky. 